\title{
The Social Aspects and Public Acceptance of Biomass Giving the Example of a Hungarian Region
}

\author{
Z. Bujdosó*, C. Patkós, T. Kovács, Z. Radics and Z. Baros \\ College professor, Mátrai út 36, Gyöngyös, 3200-Hungary
}

\section{Article history:}

Received June 12,2012 Received in revised form June 25, 2012 Accepted June 30, 2012 Available online

\begin{abstract}
Biomass energy sources are the most promising, and most heavily subsidized renewable energy sources. The future of biomass energy in the global energy system depends on on many major factors, among others on the attitude of society to the biomass energy and the renewable energy resources. The purpose of the paper is to analyze the opportunities of utilization of biomass energy sources giving example of a Hungarian study area furthermore to study the public acceptance of renewable energy sources in a certain region. The study aims to explore the general knowledge, innovative attitude, acceptance and willingness of application as well as the estimation of the benefits of the use of RES within the inhabitants. Data collection has carried out by primary (questionnaire survey) and secondary ways in order to gain deep information from the target group (local people). The conclusion we can drawn from the analysis is that society take the biomass energy into consideration and its importance and responsibility is increasing. As far as the consciousness is concerned, the knowledge and the environmental friendly approach of inhabitants are also sufficient.
\end{abstract}

Keywords: biomass potential, county of heves, renewable resources, social recognition

\section{Introduction}

The shift towards renewable energy forms is an inevitable part of strategies trying to mitigate the challenges coming from climate change. Different kinds of biomass have been important energy resources of mankind for thousands of years [1]. Recent scientific and technological innovations made possible the exploitation of these traditional resources in a more effective way. Judgement of this traditional energy resource is rather controversial nowadays. On the one hand studies all over the world state, that biomass should be used to a greater extent in the supply side of energy market. For example effective pellet stoves can give us an economic and comfortable solution of heating in private dwellings and in public buildings as well [2]. Biodiesel and bio-ethanol are expected as possible descendants of fossil fuels [3]. Nevertheless the issue is far broader than the realm of useful arts. Accordingly it is very important to evoke discourses not only on economic questions, but on natural and social issues as well [4].

On the other hand there are many opponent judgements concerning this issue. Firstly some authors think that growing demands on biomass based energy resources endanger equilibrium of natural ecosystems mainly in sensitive areas (e.g. tropical rainforests) [5]. Secondly a threat is predicted that energy demands on the rise are going to increase food prices worldwide and in poorer countries it causes famine [6]. Finally there are some sceptic opinions among professionals that these bio-fuels can never be produced economically without state subsidies (low net-energy gain) [7, 8].

These issues are far too important to deny them. Proposals to answer these crucial questions are born at global, national, regional and local level. Globally the United Nation's FAO has coordinated many programmes concerning bioenergy (e.g. Bioenergy and Food Security Criteria and Indicators (BEFSCI) Project or the FAO Support Package for Decision-Making for

\footnotetext{
* Corresponding author. Tel:+36/37/518-181

E-mail: zbujdoso@karolyrobert.hu
} 
Sustainable Bioenergy: Making Bioenergy Work for Climate, Energy and Food Security). The FAO is the institution that has the ability to co-ordinate sustainable energetically utilized biomass projects worldwide [4, 9]. The future of biomass energy in the global energy system depends on on many major factors, among others on the attitude of society to the biomass energy and the renewable energy resources [10].

We think that one of the most important factor is the local community as inhabitants can benefit the advantages of biomass energy but locals suffer its backwards. That means the increasing importance of the society which gave to us the idea to study this topic.

Heves county is located on the northern part of Hungary with very good connection to the largest cities of the country. It is a rural area with small villages where the energy production could be served by renewable sources. The aims of this analysis are on the one hand to predict the potential renewable energy of Heves County and on the other hand to research the social background of the utilisation of renewable energy sources (RES).

\section{Materials and methods}

Data collection has carried out by two ways. Primary data collection meant questionnaire survey on the public acceptance of renewable energy sources (already accomplished, interpretation is in process) while during secondary data collection data were collected from institutions (village-masters, offices of the micro-region, the Agricultural Agency of the County of Heves, census of vine-lands and orchards by the Hungarian Central Statistical Office, Hungarian National Forest Service, institutional statistics).

In order to research the social background of the utilisation of renewable energy sources (RES), questionnaire surveys were conducted for the designated target groups (inhabitants) in the study area. The study aimed to explore the general knowledge, innovative attitude, acceptance and willingness of application as well as the estimation of the benefits of the use of RES within the inhabitants.

To conduct this study, random sampling was applied for following number of units: inhabitants: 17 settlements of the County of Heves - 505 units. Below, results of the survey carried out for the first target group will be summarised.

\section{Result and Discussion}

The overall potential yield of biomass energy depends on the land area allocated to producing it.
Many of the concerns about expanding the biomass energy industry involve the possibility that new production will occupy land needed for growing food and for conservation. The justification for this concern depends on the quantity and quality of alternative lands $[10,11]$.

\subsection{An analysis of the use of energy crops}

The physical geographical, especially morphological, endowments in the County of Heves enable primarily its southern parts for crop production that has, in general, a lower share on the national level, compared to the share of population (3\%). Among the crops, the predominance of corns is typical with occupying 2/3 of the croplands. From the point of view of energy, the significant share of oil-crops and its increase can be considered as relevant.

The land of oil crops is the most significant from the national aggregate. Its value has been around $6 \%$ of the national croplands in years following the Millenium with no remarkable growth experienced. For absolute values, it is indicated that their croplands has been continuously increasing (from 24600 ha to $43250 \mathrm{ha}$ ) to a value considered to be very significant within 6 years, but still remaining around the rate of the national value. In case, their yield is examined, an increase of the relevance of these crops in the County of Heves can be witnessed.

Also, the growing of potato and sugar-beet suitable for bioethanol production should be mentioned here; whose share indicates only 1-2 \% of the national production lands, however with an increasing tendency. Also, the rate of production has significantly increased with indicating the second highest rate of increase behind the oil crops as compared to $2000(+50 \%)$. This definitely makes an adequate basis for the use for energy purposes.

Summarised, it can be claimed that in the County of Heves, primarily the share of crops suitable for the production of biodiesel and bioethanol has been increasing in recent years, however this share being far behind the magnitude order of corns. In this respect, an energy supply system operated by a mixture of raw materials is recommended.

It can be claimed that, in the area of the County of Heves, theoretically, winter wheat can be grown for energy purposes even at less favoured areas (however, it is exclusively used for feeding purposes) whereas all other crops, under the present conditions, can be used primarily for food-production (Table 1). 
Table 1

The amount of crops harvested in the County of Heves (tonnes)

\begin{tabular}{|c|c|c|c|c|c|c|c|}
\hline \multirow{2}{*}{ Crops } & \multicolumn{7}{|c|}{ Amount of crops harvested (tonnes) } \\
\hline & 2004 & 2005 & 2006 & 2007 & 2008 & 2009 & 2010 \\
\hline Corns & 192,882 & 357,085 & 176,363 & 130,120 & 394,560 & 363,716 & 291,410 \\
\hline Oil-seeds & 29,325 & 47,647 & 40,157 & 58,734 & 88,076 & 87,075 & 88,511 \\
\hline Ploughland green fodders & 43,360 & 55,458 & 46,141 & 28,372 & 43,262 & 26,279 & 33,962 \\
\hline Succulent fodders & 168 & & 4,214 & 206 & 465 & 823 & 220 \\
\hline Bite hay & 20,106 & 40,564 & 20,049 & 22,186 & 29,324 & 29,658 & 29,884 \\
\hline Seasonal turf & & & & 550 & 1,019 & 99 & 1,552 \\
\hline Fodder seeds total & 429 & 101 & 40 & 94 & 288 & 45 & 164 \\
\hline Potato & 16,465 & 15,193 & 15,301 & 5,580 & 4,572 & 4,348 & 3,767 \\
\hline Sugar-beet & 28,558 & 41,886 & 26,955 & 15,938 & 46,125 & 32,542 & 22,809 \\
\hline
\end{tabular}

Of the oil-crops, areas of the rape and sunflower are significant in the micro-region; the endowments favour the field production of these two crops (Table 2.).

Table 2

Areas of the most important oil-crops in the County of heves

\begin{tabular}{cc}
\hline Crop & Area (ha) \\
\hline Winter coleseed & 160 \\
Sunflower & 2,468 \\
\hline Source: Agricultural Agency for the County of Heves, 2010 &
\end{tabular}

In the case of sunflower, $90 \%$ of all crops is utilised as edible oil [12]. However, during the production of sunflower, a rather high amount of remnants and byproducts are resultant (dead stalk, plates). Pasturelands abandoned due to the decreased stocks of sheep and cattle as well as poor-quality plough lands can be the sites of forestation.

According to the joint regulation of the EU and the Hungarian Ministry of Agriculture and Rural Development, at least once in every 50 year, vexillaries must be planted at croplands. The acidic soils found in the County of Heves mainly facilitate the application of the acerb Lupinus spp. Having it used as a green manure is more advantageous compared to other sweet species as here no damage caused by games should be reckoned with [12].

A programme on the use of energy grass (Miscantus, Szarvasi-1 energy grass) for energy purposes was launched in the Fleischmann Rudolf Research Institute of the Károly Róbert College. This plant is, as a part of an experiment, grown within the county. Not only the rate of forested areas in the entire county exceeds the national average by $6 \%$, however is far behind of what is potentiated by the ecological potential of the county. Poor-quality plough-lands, steep turfs and pasturelands that can be abandoned could be involved in the process of renewable energy production from wood by plantation (Table 3).
Table 3

The extent of forestable abandoned pasture-lands and poor-quality croplands for the micro-regions in the County of Heves

\begin{tabular}{cc}
\hline Micro-region & Forestable area (ha) \\
\hline Gyöngyös & $9000-10200$ \\
Heves & $3600-4100$ \\
Eger & $5400-6800$ \\
Hatvan & $4300-5100$ \\
Bélapátfalva & $5400-6100$ \\
Füzesabony & $4300-5100$ \\
Pétervására & $9000-10900$ \\
In total & $41000-48000$ \\
\hline Source: Agricultural Agency for the County of Heves, 2010 &
\end{tabular}

At these areas, within 15-25 years, a timber yield of 84000 bm3, i.e. ca. 35000 tonnes of biomass can be reckoned with [12]. This represent a further $518000 \mathrm{GJ}$ of energy, i.e. a significant amount of forestry biomass potential within the County of Heves. One of the preconditions of utilisation is the appropriate selection of wood species. In case of production for biomass purposes, the plantation of species with a relatively short growth time, as well as the re-introduction of crop rotation of 30 to 40 years, classified as short for slowpropagation species.

\subsection{Public acceptance of renewable energy sources in the study area}

The main segment of the questionnaire compiled for inhabitants contains questions on renewable energy sources. First, we intended to obtain information on the type of RES that the pollees had already heard anything at all. In this respect, according to the responses given, solar energy, wind energy and hydro-power (with a general knowledge exceeding 90\%) proved to be the most well-known. The share of those had not heard about any of these technologies is only $1.4 \%$.

The knowledge on various bioenergy-related technologies can be regarded in general as moderate. Only somewhat $20 \%$ of the respondents had heard about short-rotation forestry, whereas bio-briquette has knowledge of $22.6 \%$ and bio-ethanol has nearly 
$25 \%$ - by this, them being the least well-known after photovoltaic technologies. On the contrary, knowledge on biogas, biodiesel and the combustion of biomass exceeds $40 \%$. The ratio of those obtaining at least basic knowledge on renewable energy sources indicates a similar tendency however with significantly lower values. Although many of the pollees have a rather explicit knowledge on these technologies, this fact is not indicated by the overall picture.

As the source of information, $85.74 \%$ of the pollees indicated television or radio, this figure followed by $61.78 \%$ of the press with far ahead all other categories. By this, our supposal according to which they are the primary channels of the spreading of information is seemed to be proven; apparently, it is also contributed by the low number of internet connections. Nevertheless, the important intermediately role played by them is clearly drawn. In addition to this, the role of education can be mentioned, with especially the fact strongly emphasized that it should be strengthened at secondary school level (Fig 1).

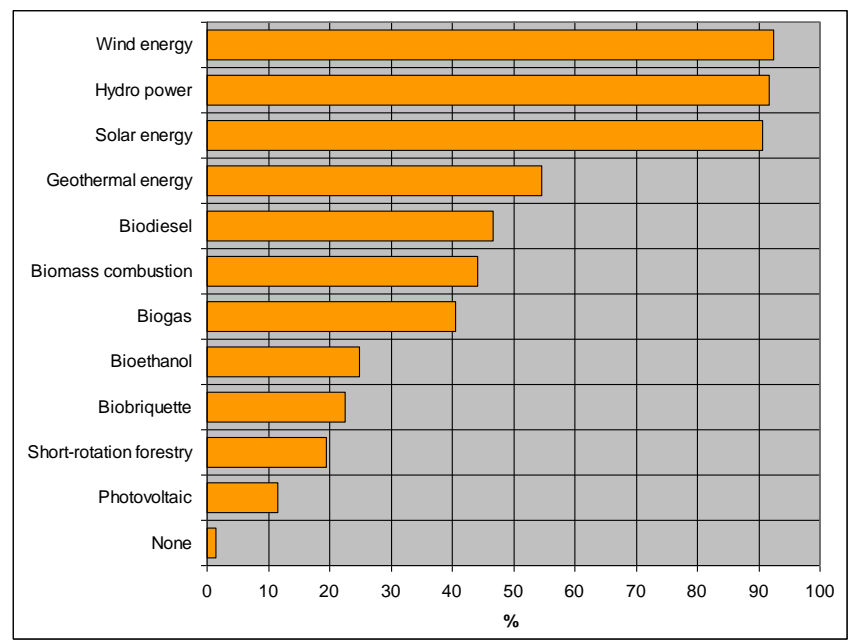

Fig. 1 The general knowledge on renewable energy sources among the citizens (in percent)

Among the most important benefits in relation to the use of RES, environmental aspects proved to be the most relevant (87.72\%). The respondents are, apparently, aware of the non-polluting nature of RES as well as of the fact that by the use of these technologies, cheaper energy compared to fossil energy sources can be produced (60.79\%). Following this aspect, the possibility of local energy production was indicated by the most pollees (44.55\%). Other options - making use of agricultural areas of poor quality, the improvement of employment, etc. represent more or less similar percentages (ca. or under 20\%). Knowledge on the funding available (e.g. funding demandable form municipalities, energy efficiency or energy saving programmes) is minimal (Fig 2).

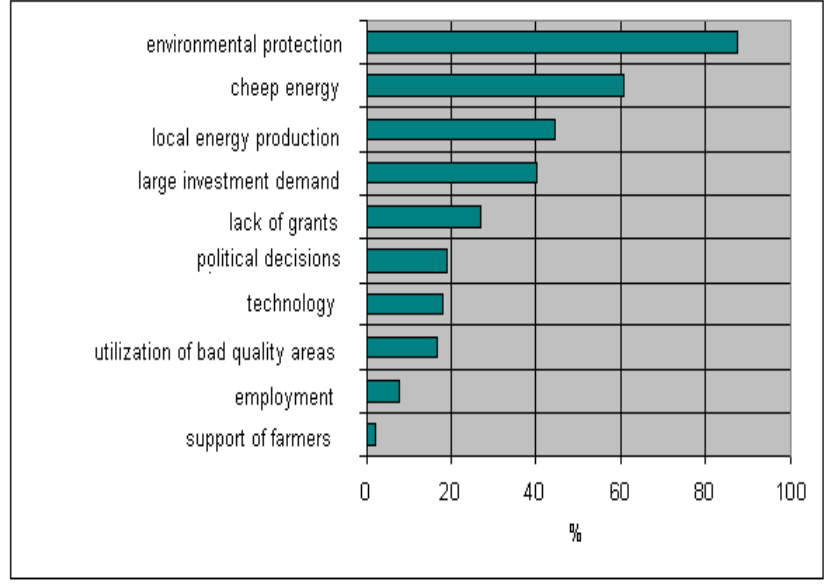

Fig. 2 Benefits in relation to the use of RES (in percent)

In the final section of the questionnaire, the inhabitants were asked about the realisation of a hypothetic installation utilising RES, in connection to whether it would be supported and if yes, on what way and degree, what organisation should take the role of initiator, whether the settlements or those involved would benefit from such investment and whether such an installation would be accepted in the environment of the residence.

The share of those opposing this type of investments has proved to be rather significant (approximately $25 \%$ ) despite which openness was experienced towards such new technologies. Half of the respondents offer primarily no-financial support. The share of those offering financial contribution to the establishment of such installation remains under $10 \%$.

Regarding financial contributions, the results indicate that inhabitants intend to make contributions in order to establish such an installation primarily by the taxes paid (36.24\%). The share of those who do not intend to devote any sum on such purpose is rather considerable $(44.75 \%)$.

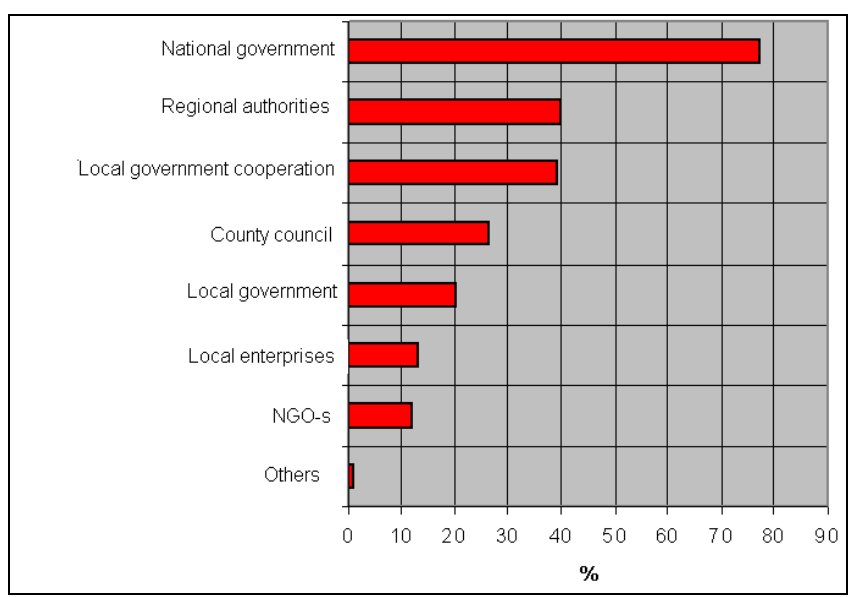

Fig. 3 The role of initiators regarding the investments connecting to renewable energy investments (in percent) 
The role of initiator considered to be necessary to such projects, is put on by nearly $80 \%$ of the pollees to the central government. The relevance of regional institutes and municipalities of the settlements within the county remains moderate $(40 \%)$. Far behind of these are all other responses giving such role to other potential actors, as e.g. civil organisations, entrepreneurs, among others (Fig. 3).

On the judging of benefits of an RES-related development on the level of settlements it can be claimed that about half of the inhabitants are aware of the fact that an installation to be implemented would not only bring environmental (cleaner air) but also socio-economic benefits (increasing tax revenues, creation of jobs). Only $11.68 \%$ thought that an investment of this kind would prove to be disadvantageous. A similar picture is drawn for the benefits on the level of individuals; however socioeconomic benefits for the inhabitants are recognised by significantly less $(23.17 \%)$ than in the previous case.

No significant opposition was experienced against a RES project to be implemented in the neighbourhood of the residential area, only four of the respondents claimed to disapprove any of this kind of installations. The lowest number of those with support to these investments would approve a biomass-based heat power plant or a smaller hydro-power plant. The low rate of support for this heat power plant is due to the opposition against chimneys and smoke and dust not to the wood as raw material. Installation related to the use of wind and solar energy, among them especially solar cells and wind wheels enjoy much greater support.

\section{Conclusion}

The study have showed that one of the most important factor is the local community as inhabitants can benefit the advantages of biomass energy but locals suffer its backwards. That means the increasing importance of the society which gave to us the idea to study this topic

The conclusion we can drawn from the analysis is that society take the biomass energy into consideration and its importance and responsibility is increasing. As far as the consciousness is concerned, the knowledge and the environmental friendly approach of inhabitants are also sufficient.

In the County of Heves, a number of actors, adjunct to the biomass industry is present. As well as they can be competitive with each other, in order to achieve success, networking among them, to which a possibility for clusterization, is also required. Within the region, the establishment of a regional cluster in type can be implemented as the actors of the industry are geographically concentrated.

\section{References}

[1] Hadiyanto, Sumarno, Rostika RN, Handayani NA (2012) Biofixation of Carbon dioxide by Chlamydomonas sp. in a Tubular Photobioreactor. Int. Journal of Renewable Energy Development 1: 10-14.

[2] Ingerson A (2009) Wood Energy Options for the Mahoosuc Region. A Community Wood Energy Guide. http://www.mahoosucinfo.org/mah_bioenergy_final.pdf 46 p.

[3] Coyle W (2007) The Future of Biofuels: A Global Perspective. Amber Waves 5(5): 24-29.

[4] Scheer H. (2007) Energy Autonomy. The Economic, Social and Technological Case for Renewable Energy. EarthScan, London. Sterling, V.A. 321 p.

[5] Leemans R, Kleidon A (1996) The Land Cover and Carbon Cycle Consequences of Large-Scale Utilizations of Biomass as An Energy Source. Global Environmental Change 6(4):335-357.

[6] Schadem C, Pimentel D (2009) Population Crash: Prospects for Famine in The Twenty-First Century. Environ. Dev. Sustain. 12(2): 245-262.

[7] Hall DO (1997) Biomass Energy in Industrialised Countries-A View of The Future. For. Ecol. Manage. 91(2): 17-45.

[8] Hill J, Nelson E, Tilman D, Polansky S, Tiffany D (2006) Environmental, Economic, and Energetic Costs and Benefits of Biodiesel and Ethanol Biofuels. Proc. Natl. Acad. Sci. 103(30): 11206-10.

[9] Hoogwijk M, Faaij A, Eickhout B, de Vries B, Turkenburg W (2005) Potential of Biomass Energy Out to 2100, for Four IPCCSRES Land-Use Scenarios. Biomass Bioenergy 29(2): 225257.

[10] Christopher BF, Campbell JE, Lobell DB (2007) Biomass Energy: The Scale of The Potential Resource. Trends in Ecology and Evolution 23(2):65-72.

[11] Haberl H, Erb KH, Krausmann F, Gaube V, Bondeau A, Plutzar C, Ginrich S, Lucht W, Fisher-Kowalsky M (2007) Quantifying and Mapping The Human Appropriation of Net Primary Production in Earth's Terrestrial Ecosystems. Proc. Natl. Acad. Sci. 104 (31):12942-47

[12] Gergely S (2009) Zöldenergia potenciál Heves megyében (Green Energy Potential in the County of Heves). $2^{\text {nd }}$ ed. Gyöngyös $245 p$. 